Turkish Online Journal of Qualitative Inquiry (TOJQI)

Volume 10, Issue 4, October 2019: 386-408

DOI: $10.17569 /$ tojqi. 598606

Research Article

\title{
Elementary School Students Designing Engineering-Based Rube Goldberg Machine Projects: A Case Study
}

\author{
Engin Karahan ${ }^{1}$, Ahmet Oğuz Akçay ${ }^{2}$, Ceren Tiftikçi ${ }^{3}$
}

\begin{abstract}
The literature highlights the importance of engineering design processes for bringing students in interdisciplinary knowledge and skills. Considering the potential of designing Rube Goldberg Machines in STEM education, this study aims to portray the experiences of fourth grade students designing Rube Goldberg machines in an after-school program for six weeks. A single case study design that approaches an analysis unit holistically was employed. The participants of the study are four fourth grade students (a design team with three female and one male students). The data collection tools were semi-structured interviews and participant observation. The analysis of the data were done via content analysis by creating categories and then themes. The themes that emerged based on the data analysis were design process, use of disciplinary knowledge, use of skills, difficulties faced, problem solving, teamwork cooperation and communication, the comparison between project design and classroom practices, learning, and the role of educator. The findings of the study illustrated the design process and the knowledge and skills they obtained from their own perspectives.
\end{abstract}

Keywords: STEM education, Rube Goldberg machines, case study.

\footnotetext{
${ }^{1}$ Assistant Professor, Eskişehir Osmangazi University, Faculty of Education, Educational Sciences, karahan@umn.edu, https://orcid.org/0000-0003-4530-211X

2 Assistant Professor, Eskişehir Osmangazi University, Faculty of Education, Primary Education, oguzakcay42@gmail.com, https://orcid.org/0000-0003-2109-976X

${ }^{3}$ Undergraduate Student, Eskişehir Osmangazi University, Faculty of Education, Mathematics and Science Education, cerentiftikci@gmail.com, https://orcid.org/0000-0002-6354-8845
}

Received:30.07.2019, Accepted: 07.10.2019 


\title{
İlkokul Öğrencilerinin Mühendislik Tasarım Odaklı Rube Goldberg Makineleri Tasarımları: Bir Durum Çalışması
}

\begin{abstract}
Öz
Eğitim alanında gerçekleştirilen çalışmalar mühendislik tasarım süreçlerinin disiplinlerarası bilgi ve becerilerin öğrencilere kazandırılması açısından öneminin altını çizmektedir. Rube Goldberg Makineleri tasarımının STEM eğitimi ve mühendislik tasarımı noktasındaki potansiyelinden yola çıkılarak, bu çalışma kapsamında ilkokul 4. sınıf öğrencilerinin okul dış1 etkinlikler kapsamında altı hafta boyunca Rube Goldberg Makinesi tasarımı sürecindeki deneyimlerinin ve edinimlerinin ortaya konulması amaçlanmaktadır. Bu doğrultuda tek bir analiz biriminin (ilköğretim dördüncü sınıf öğrencilerinin oluşturduğu tasarım ekibi) kapsamlı bir biçimde ele alındığı bütüncül tek durum deseni temel alınarak çalışma yürütülmüştür. Araştırmanın çalışma grubunu bir devlet okulunda dördüncü sınıf düzeyinde öğrenim gören dört öğrenci (3 kız 1 erkek) oluşturmaktadır. Veri toplama araçlarını yarı-yapılandırılmış görüşmeler ve katılımcı gözlemleri oluşturmaktadır. Verilerin analizinde, birbirine benzeyen verilerin belirli kavramlar ve temalar çerçevesinde bir araya getirilerek yorumlanmasını amaçlayan içerik analizi yöntemi uygulanmıştır. Verilerin analizi neticesinde ortaya çıkan kodlar: tasarım süreci, disipliner bilgilerin kullanımı, beceri kullanımı, karşılaşılan güçlükler, problem çözme, ekip çalışması işbirliği ve iletişim, proje süreci ve sınıf içi uygulamaların karşılaştırılması, öğrenme ve eğitmenin rolüdür. Çalışmanın bulguları öğrencilerin gözünden tasarım sürecini ve bu süreçte kazandıklarını düşündükleri bilgi ve becerileri ortaya koymuştur.
\end{abstract}

Anahtar Sözcükler: STEM eğitimi, Rube Goldberg makineleri, durum çalışması. 


\section{Introduction}

\section{STEM Education}

Being rapidly changing and an undeniable part of education, technology is included in the curriculum and strategy documents of countries. In this way, students are taught about $21^{\text {st }}$ century technologies, and attempts are made to ensure awareness of innovations occurring in technology and engineering (Azgin \& Şenler, 2019). Based on the first letters of science, technology, engineering and mathematics, STEM education is a current approach based on teaching that brings students' knowledge and skills in these areas together and targets the use of abstract knowledge in real world contexts. Especially at the K-12 level, mathematics and sciences are taught as independent disciplines in formal learning environments. However, though these disciplines integrate with technology at a basic level, the relationship with the field of engineering is mostly not explained (Öner \& Capraro, 2016). Though all science and mathematics topics are not appropriate to form interdisciplinary connections, there is great potential to create connections between the four disciplines in an integrated structure due to the nature of STEM education (İnce, Misır, Küpeli, \& Firat, 2018). STEM education "has the properties of being an educational approach that aims to apply theoretical knowledge, transforming it into products and innovative inventions; ensuring students see the knowledge learned in lessons as part of a whole, and included on the curriculum of many countries around the world" (Ministry of National Education [MEB], 2016).

STEM education may be implemented by integration of science, technology, engineering and mathematics disciplines with equal weight or by taking one of these disciplines as center and creating connections with the other STEM disciplines. Studies in the relevant literature show that STEM education targets the development and gain of higher-level cognitive skills in students (Özyurt, Kayıran, \& Başaran, 2018). STEM education ensures students learn from real world problems and can solve the problems that will be encountered in the future, obtain knowledge in more holistic and planned manner, transfer the knowledge learned to different disciplines and complete production and outcomes using skills specific to different fields at an early age (Aydın, Saka, \& Guzey, 2017). Among the basic targets of the STEM approach is that students gain $21^{\text {st }}$ century skills by increasing their interest and orientation toward the 
science, technology, engineering and mathematic disciplines. Though $21^{\text {st }}$ century skills have many definitions, they basically comprise "living and occupational skills", "learning and renewal skills" and "information, media and technology skills" (Partnership for 21st Century Skills, 2009). In other words, STEM education ensures the gain and development of many skills like students' confidence in themselves, problem-solving, gaining life experience, being innovative, communication, creativity, intellectual curiosity, critical thinking, information and media literacy, cooperation and team work, and self-direction and social responsibility (Morrison, 2006; Aydın, Saka, \& Guzey, 2017; Partnership for 21st Century Skills, 2009).

Research by Pekbay (2017) concluded that STEM activities were effective in increasing students' interest in STEM fields. Within the scope of this study, STEM was described as "students focused on concepts like inventing, discovering, combining, constructing, developing ideas, creativity, innovation, development of countries and intercountry competition were identified to have more sophisticated opinions related to STEM after the application compared to before the application" (Pekbay, 2017). Similarly, Şahin (2013) stated that students' interest in STEM fields increased with participation in STEM activities related to real life. It is considered that students with learning experiences based on STEM education are individuals who can solve problems, are innovative, have high self-confidence, think logically, and are science and mathematics literate, in addition to reaching capacity in careers related to the science fields (Bahar, Yener, Y1lmaz, Emen, \& Gürer, 2018).

\section{Engineering Design}

Scientists in the process of understanding and discovering nature, the main theme of the sciences, benefit from products designed by engineers and achieved by using technology; similarly, engineers use the scientific principles discovered by scientists when making designs and are aided by technology in removing obstacles to design. Current research has revealed the need for science education, including many disciplines within its nature and based on research/questioning, enriched with engineering design approaches (Topalsan, 2018). "Acting as a bridge between engineering, science and mathematics-based theories and technology used, with the aim of resolving social requirements, and acting to integrate scientific principles and mathematical theories, it is emphasized that engineering design-based approaches have great importance for the development of science education" (Bahar et al., 2018). 
The engineering process may be defined as having knowledge, using this knowledge to design new things, understanding how these designed objects work and making this design appropriate for others (Brophy, Klein, Portsmore, \& Rogers, 2008). As engineering is directly related to real situations and social processes, at its foundation it is based on common work by a group of people in the name of solving personal and social problems (Marulcu \& Sungur, 2013). Engineering design activities develop students' independent, reflective and metacognitive thinking skills and ensures they gain qualities by learning from experiences and mistakes within this process, and considering uncertainty, risk and safety factors (Moore, Glancy, Tank, Kersten, \& Smith, 2014). Engineering design applications in the context of STEM education integrate knowledge and skills in the STEM field with interdisciplinary approaches based on students' problem-solving ideas for real life problems (Bybee, 2010; Guzey, Tank, Wang, Roehrig, \& Moore, 2014).

However, traditional classroom applications may not always fully allow gain of skills targeted by completing STEM-focused engineering design activities due to physical conditions and curriculum structures in schools (Roberts, 2012; Bybee, 2010). As a result, a significant portion of STEM-focused activities appear to be completed in extracurricular environments (Davis and Hardin, 2013; Hesser and Schwartz, 2013; Bevan, Gutwill, Petrich, \& Wilkinson, 2014). Hence, the process based on operation of complicated mechanisms to achieve simple tasks of Rube Goldberg machines provides the opportunity to use interdisciplinary knowledge and skills through developing problem-solving-focused projects and has great potential to achieve the targets of the STEM education approach (Ambrose \& Sternberg, 2016). These machines ensure students develop unique engineering designs (Acharya \& Sirinterlikci, 2010; O'Bryne et al., 2018; Marklin, 2018).

Similarly, Rube Goldberg machines not only integrate STEM concepts, they also require students to creatively develop machine designs (O’Byrne et al., 2018). Rube Goldberg (18831970), in addition to being an engineer, was also a popular Pulitzer prize-winning caricaturist known for strange inventions. In addition to being known for his caricatures, he designed machines completing simple tasks with a range of complicated steps and gave these machines the name "Rube Goldberg machine". A Rube Goldberg machine (RGM) is a complicated structure using a chain reaction to complete a simple task. To create RGM, students must not only use knowledge accumulated about disciplines like science, mathematics and engineering, they must also have competencies like humor and story-telling. Marklin (2018) stated that Rube 
Goldberg machines were not just drawings, they also revealed innovative engineering designs, while Acharya and Sirinterlikci (2010) stated Rube Goldberg machines used engineering designs. Kim and Park (2012) stated that Rube Goldberg machines supported the development of positive attitudes to science among students. As a result, it is considered possible to use Rube Goldberg machines for students to gain STEM knowledge and skills and to inform them about engineering.

Based on the potential for design of Rube Goldberg machines at the juncture of STEM education and engineering design, this study aimed to reveal the experiences of $4^{\text {th }}$ grade students during a six-week Rube Goldberg machine design process completed in the scope of extracurricular activities. Thus, in depth investigation of the design process for Rube Goldberg machines in terms of both learning outputs and explaining the thinking and experiences of students during this process was ensured.

\section{Method}

The aim of the study is to reveal the experiences and gains of fourth-grade primary school students during the design process for STEM-focused Rube Goldberg machines. As a result, a case study design, based on in depth "how" and "why" questions and allowing investigation of a case or event not controlled by the researcher was used (Yıldırım \& Şimşek, 2011). In line with this, the study was completed on a single analysis unit (design team formed of fourthgrade primary school students) comprehensively dealt with in a holistic single case pattern.

\section{Participants}

The study group in this research comprised four students attending fourth-grade level in a public school (3 girls, 1 boy). Within the scope of the STEM club, with voluntary participation of students after school, they worked on the Rube Goldberg Machine design process for six weeks. Three of the students were in the same class, while one was in a different class.

The first participant, Gökhan, though a very problematic student in terms of distraction and self-confidence, came to the fore with the ability to find rapid and practical solutions to problems. Able to criticize his own performance, Gökhan was delayed in catching up with the 
remainder of the group when completing group work. Another participant, Melike, chose to work as a team instead of individually during group work and was a student able to lead the group. Coming to the fore among her friends due to problem-solving skills, she occasionally displayed panic behavior due to her excitable nature. The third participant, Ceylan, was shy; however, she effectively completed cooperative work during group studies. She chose to act slowly and deliberately during the process of solving problems in general. Finally, Hacer came to the fore among her friends due to esthetic perceptions and high manual skills. She was able to find more than one solution during problem-solving but had a tendency to dominate the problem-solving process.

\section{Design Process}

The aim with the design process was to develop thinking skills of students like critical thinking, creativity, innovativeness and problem-solving, as well as making this process an entertaining alternative learning activity. Participating students used their STEM understanding to define the problem and worked in line with the plan prepared by developing solution proposals in this process. During the six-week design process, the skills gained by the students, things noted during the design processes, how they completed team work, and what knowledge and skills were used were investigated by communication with the teachers.

At the end of the process, students were expected to complete the final step of opening a flag with the desired machine created in 6 steps. These steps are the transfer of energy from one action to another. For example, a sequence of dominos hitting each other is 1 (one) step. One hundred dominos falling is a repeated situation at the heart of Rube Goldberg machines and counts as a single step. Table 1 shows the design process.

\section{Table 1}

\section{Design Process}

\begin{tabular}{ll}
\hline 1st week & $\begin{array}{l}\text { General information about RGM, question-answer and planning of } \\
\text { student designs (drawings) }\end{array}$ \\
2nd week & Bringing materials and beginning project design \\
3rd, 4th and 5th weeks & Continuation of project design \\
6th week & Completion and presentation of project design \\
\hline
\end{tabular}


In the first week of the process, participants were given general information about RGM by the researchers and shown examples. Within the scope of the information, the properties required by the RGM nature were mentioned, what the number of steps are, the importance of valid energy transfer for the number of steps, in other words the trigger factor, what type of materials will be used (recycling or easily obtained material), and what the target of the design was (opening a flag) were explained in detail. Student questions were answered and misunderstood sections were explained in detail and then students created sketch drawings when planning their designs. In the $2^{\text {nd }}$ week, students brought material to be used in line with their plans and began to create the mechanism. In the $3^{\text {rd }}, 4^{\text {th }}$ and $5^{\text {th }}$ weeks, students continued to create their designs, and replaced missing or nonfunctional materials with more appropriate ones to ease operation of the mechanism. During these three weeks, steps planned in the first week but not operational during the design process were updated and work continued. In the $6^{\text {th }}$ week, students completed the mechanism, made it operational and presented it to their friends.

\section{Data Collection Tools}

In qualitative research, data obtained from different sources like observations and interviews are analyzed, synthesized and interpreted (Yıldırım \& Şimşek, 2011). The data collection tools in this research comprised semi-structured interviews and participant observations. Interviews target the determination of experiences of participants and how these experiences are shaped. In this study, semi-structured interviews with individual participants targeted their perspectives about the experiences and outcomes they gained during the process. In addition to interviews, the researchers were in continuous interaction with the participants during the process and described their experiences with a participatory observer role.

\section{Data Analysis}

Analysis of data in this study brought similar data together in the framework of certain concepts and themes and applied a content analysis method targeting interpretation. In this process, categories and themes revealed by coding of data were used to interpret data. The coding process for data was separately completed by three researchers, then combined and consistency between coders was ensured. Additionally, the interview and observation data were examined 
to see if they supported each other, in order to increase the validity and reliability of the research (Yıldırım \& Şimşek, 2011).

\section{Results}

With the aim of communicating the experiences and gains of participants during the RGM design process, the responses to semi-structured interview questions and findings from the researchers' observations were first coded, then sorted into categories, and finally used to build themes. Some responses of the students to questions during the interview were included in more than one code. The themes are shown on Figure 1. Categories are also presented within the themes.

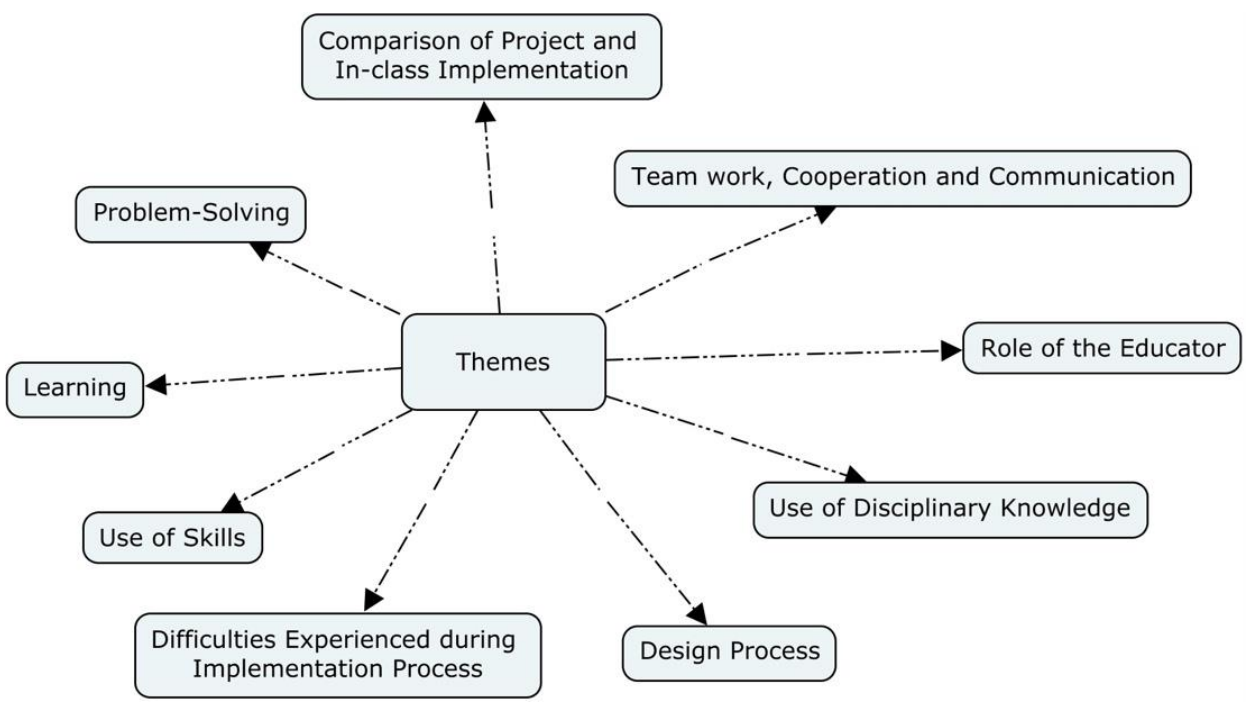

Figure 1. Basic Themes Revealed by the Analysis

\section{Design Process}

Categories included in the theme of "design process" are ingroup decision making, compliance with sketch drawings, developing their own material and learning from errors. The students developed sketch drawings of the machines at the start of the process and progressed through the process in line with the general lines of these drawings. However, material representing a problem in their developed mechanism was exchanged with more efficiently operating material through problem-solving. In short, while remaining true to the design plan developed at the 
start of the process, they exchanged problematic pieces. For example, the first design attempted did not allow sufficient car energy transfer, so a heavier car was found and the problem was solved within the same sketch plan. In the following example, Gökhan explains improving the design with material exchange.

"First of all, we made mistakes. We designed thinking how we could make it work. Then as we didn't have sponge (recycled polymeric material) we tried to widen some areas. Then when we widened it too much, the marble fell through the center of the sponge. Later we fixed the sponge as we had it at first. Then we used a cardboard cup the same as in our drawing. Then it worked." (Interview-Gökhan)

Additionally, along with remaining loyal to the sketch drawing, material that did not fully operate in the mechanism was exchanged with similar but deeper operating material and they developed their own materials.

"Design material was determined by the students using material they didn't use brought from home. Some material was designed with their families in order to make it more appropriate for use." (Observation note)

During the interviews with students, they stated that their imagination had developed throughout the process and they could do better drawings than at the beginning. Additionally, it was observed that participants made consensus decisions with ingroup discussions during the design process.

"The four friends state their own ideas, and after a brainstorming session, they apply the most logical idea." (Observation note)

\section{Use of Disciplinary Knowledge}

Weight and force concepts, thrust, force-energy relationship, control of energy transfer, stating and solving problems, and use of nonstandard measurement devices are categories within the "use of disciplinary knowledge" theme. Students stated they used information from different disciplines during the process of creating the mechanism. They used concepts and knowledge included in science and mathematics lessons especially. To operate the mechanisms correctly without errors, they used knowledge about weight, velocity, force, thrust, and energy, in addition to problem statement and solving skills frequently encountered in social science 
lessons to solve problems during the process. For example, the participant Hacer said they used knowledge learned in science lessons.

"We used weight and force terms. For example, when trying to find the answers to questions like; will that lift the weight? Will that force push that object? We used what we learned in lessons." (Interview-Hacer)

Additionally, in line with data obtained as a result of observations, the students show how the rectangular shape of Jenga pieces allowed them to fall in regular fashion. The students expended efforts to place them at equal intervals to ensure the step continued and were observed to use the nonstandard measurement tool of fingers to determine the distance between the Jenga pieces.

"In this mechanism where energy transfer is most important, students corrected mistakes related to energy transfer in each step because they could not always change the material." (Observation note)

\section{Use of Skills}

Categories included in the "use of skills" theme were thinking skills, manual skills, problemsolving skills, communication and cooperation skills, creativity and inability to associate with skills. For students to operate the mechanism in regular manner during the process, they stated they frequently used manual skills. The observation note given below reveals the manual skills developed by students during the process.

"At the start of the process, when students attempted to insert pieces of the mechanism, it caused the other pieces not to work. Over time, with the development of hand skills during the process they succeeded in building the mechanism without errors." (Observation note)

During the process it was observed that students' awareness and sufficiency levels about skills were insufficient. For example, one of the students considering her skills insufficient said to her friends during the design process in fact my manual skills are good, I just noticed (observation note) and to the researcher during the semi-structured interview "my manual skills were poor, I gained more manual skills" (Interview-Melike). 
Additionally, as they used teamwork within the scope of RGM design, they used communication and cooperation skills and found the most appropriate solution for problems encountered by discussion. The participant Melike expressed her thoughts "I learned the skill of being a team with my friends, of sharing ideas" (Interview-Melike).

In addition to all of this, participants emphasized the development of design skills during the process, and that if they entered the design process again they would make better designs.

"After students built the mechanism, they became aware of what RGM are and what type of RGM they could make. If they did it again, they stated they would make different steps." (Observation note)

\section{Difficulties Experienced during Implementation Process}

Problems during step transfers, clarification of RGM steps and attention errors are categories under the "difficulties experienced during the implementation process" theme. Students experienced difficulty with the step transfers due to the setup of the material used and inappropriate steps. For example, among difficulties experienced when building the mechanism, due to the marble used for step transfer being too small, the car in the next step didn't move.

"They think they can reach a conclusion by only thinking once about the error in a step. Then they repeat that step maybe 10 times and realize they can solve the problem." (Observation note)

Additionally, students think about one step as two or three steps and experienced difficulty when calculating the numbers of steps in the mechanism. For example, they calculated every block the marble knocks as a step; however, they ignored the need to transfer energy from one action to another in order to count as a step. In other words, students could not calculate a repeated situation as a single step.

"Due to the lack of clarity about what steps are in the RGM setup, within the group they could not determine the number of steps and energy transfer." (Observation note) 


\section{Problem-Solving}

Trial and error, problem solving by discussion, mentor support, determination of the most appropriate solution and focused problem-solving are categories within the "problem-solving" theme. Instead of finding a single solution to problems encountered, the participants stated they developed more than one solution and determined the most appropriate solution by trial and error and then applied it. For solution to problems encountered at the beginning of the process, students all talked at once without listening to each other's ideas, and they made more errors as everyone wanted to apply their own ideas. In the advanced stage of the process, they began to listen to each other and stated they used brainstorming to reduce errors to a minimum and shorten the solution process for problems.

"Sometimes at solution points we had discussions like "this should be like that". But we combined our ideas and all of us solved the problem." (Interview-Hacer)

Additionally, when students could not produce a solution, they chose trial and error and stated they solved the problem in this way. The participant Gökhan expressed his thoughts about the problem-solving process with trial and error in the advancing stage of the process.

"Firstly, we found the problem by trying over and over. Then we saw where we made the mistake. We corrected the mistake by thinking, seeing and trying." (Interview-Gökhan)

More than one participant stating their opinion sometimes made it difficult for students to focus on the design. This situation presented an obstacle to solving problems encountered. In the advancing process, they gained the competency to find the solution by focusing on the problem.

"No matter how many changes they make to the mistaken location, when they see the RGM mechanism still does not open the flag they find the error they have focused on is not the mistake and the error is in a different part of the mechanism." (Observation note)

Additionally, in situations where they could not find a solution through trial and error, they said they applied for mentor assistance.

"Firstly, I talked to my friends, and I tried to solve the problem by discussion. If I couldn't solve it, I went to the teacher." (Interview-Hacer) 
"I gave the students a long time to find their mistake, sometimes half an hour sometimes longer. When students could not find a solution in any way, they received support from me." (Observation note)

\section{Team work, Cooperation and Communication}

Communication problems, cooperative problem-solving, solving disputes by consensus, sharing responsibility and duty, and listening and applying ideas are categories included under the "teamwork, cooperation and communication" theme. At the beginning of the process, students experienced disagreements about what the steps of the mechanism should be and which material they should use. In later stages, they observed that disagreements were an obstacle to their progression. As a result, they reached solutions through discussions and consensus.

"Sometimes I had problems. I couldn't do some things. Our cooperation was good. My communication was not very good.” (Interview-Gökhan)

"Though group members experienced communication problems at the start, the need for cooperation began to resolve communication problems" (Observation note)

Additionally, they shared duties in order to continue the process more effectively and correctly. For example, instead of one person providing materials, they talked and decided that everyone should bring what material they had. In another instance, as two students were in the same class and another was their friend, the remaining student was observed to experience communication problems. At the start of the process, the other students did not listen to this student's ideas and this caused communication problems between the group members. However, in the advanced stages of the process, the group adapted to the unintegrated student and they maintained the process in healthier fashion.

"At the beginning, the group leader displayed dominant attitudes in solving problems. Later when the solution ideas of a passive student were found to work, the whole group began to determine problems and find common solutions" (Observation note) 


\section{Comparison of Project and In-class Implementation}

Similarity to class experiments, direct experience of the student, richer experience compared to in-class implementation, more opportunity for cooperative work, regular completion each week, and three-dimensions studies focused on experience different from books are categories under the theme of "comparison of project and in-class implementation". Under this theme, students mostly emphasized being active within the process. Classes are crowded for experiments and activities and due to lack of time, they mentioned they could not fully complete experiments in the class environment.

"In school lessons there are these types of experiments in the science book. There are similar ones. But they are experiments we don't do. RGM was different. We did it ourselves." (Interview-Melike)

"For example, in class when we do experiment type things the class is very crowded so we don't fully do them. Everyone says different things and we don't do it. With the people in STEM club I can do it more comfortably and quickly." (InterviewCeylan)

As stated by the student, because the classes are crowded during experiments and activities, students are not individually active and the teacher cannot pay much attention to students individually. As the design teams within the scope of this study contains 4-5 people, the mentors were able to pay more and better attention to students individually and students have the opportunity to discover for themselves better in this way. Additionally, participants revealed that learning experiences with more concrete materials instead of written texts in lessons was a positive factor affecting their learning experience.

"Differently, this time there was no test or book, we began to do things based more on manual skills. We made the three-dimensional reality" (Interview-Gökhan)

\section{Learning}

Project design and development, slope-velocity relationship and sloped plane system were categories under the "learning" theme. During interviews with students when giving responses to questions about what they learned, they emphasized project design and development. 
Students who don't have the opportunity to work on projects during formal education processes stated designing and developing a project from the start (Interview-Ceylan) came to the fore when asked questions about what they learned in relation to the process. As a result, participants mentioned that they obtained the necessary skills for project design during this process.

Another important point revealed in the learning theme is that students had the opportunity to learn some content and skills not included on the curriculum at their grade level through observation and experience. For example, by trial and error at the point of moving objects in the mechanism, they were observed to discover the correlation between slope and velocity.

"Attempts were made to control velocity increases due to the steep slope after trials and in this way students discovered the relationship between slope-velocity." (Observation note)

In addition to the slope-velocity relationship, the students were observed to learn concepts they did not know before the process like sloped plane system, friction force and energy transfer.

\section{Role of the Educator}

Categories included in the "role of the educator" theme are supporting with clues, correcting mistakes, undertaking the teacher's role, gaining awareness of problems and awareness of mistakes. Students encountered problems at times during the process of creating the mechanism and they experienced difficulties solving these problems. The educators came into play and made the students aware of where they were making mistakes, and showed the students how to find possible solution routes by giving clues. The aim here was to allow the students to become aware of the problem and correct their mistakes rather than directly giving them a solution. Additionally, students gave the educator the role of teacher during the process. The participant Hacer expressed her thoughts as follows.

"I saw you as a teacher. You helped use to correct our mistakes." (InterviewHacer) 
The educator working one on one with the participant group occasionally asked them openended questions in order to make the participants aware of their mistakes. However, as much opportunity as possible was given during this process, with support given only at the last point.

"I gave the students a long time to find their mistake, sometimes half an hour sometimes longer. When students could not find a solution in anyway, they received support from me." (Observation note)

\section{Discussion and Conclusion}

The results of the analysis of data collected from fourth grade primary school students about the STEM-focused Rube Goldberg machine design process aimed to reveal the experiences and gains of these students. The findings of the study revealed the design process from the student's point of view and the knowledge and skills that students considered themselves to have gained from the design process.

Deveci (2019) emphasized the importance of researching the efficacy of Rube Goldberg machines in scientific concepts. The results of semi-structured interviews and observations completed within the scope of the research observed that participants learned science and mathematics concepts on the primary curriculum better and gained awareness of knowledge at upper teaching levels. Studies in the literature underline that engineering design processes target transformation of knowledge into learning and applications (Brophy, Klein, Portsmore, $\&$ Rogers, 2008), in addition to the development of upper-level cognition skills (Özyurt, Kayıran, \& Başaran, 2018). The findings of this study support these arguments showing that students transformed knowledge and skills specific to science and mathematics disciplines, especially, in the design process and had high awareness of the process. The participants discovered concepts and relationships included in higher class outcomes through observation and experimentation and were revealed to have self-awareness about this learning process.

Another important point revealed in the research findings is the change in the cooperationbased teamwork skills of participants during the design process. Studies in the relevant literature about Rube Goldberg machines show students experienced problems with team work and management during this design process (Jordan \& Pereira, 2009; Mahinroosta; \& Lindsay, 2016). Participants experiencing problems at the point of decision making and sharing 
responsibility in the process contributed more to efficient cooperative processes as the project advanced. Students stating their learning experiences in the RGM design process were different to those in classroom environment during the semi-structured interviews emphasized that they had more opportunity for cooperative work during the design process compared to in-class implementations. As a result, the problems experienced by students who were not used to teamwork at the beginning of the process are normal and the experience gained during the process appeared to positively contribute to skills like cooperation, teamwork, and responsibility. With an important place in 21 st century skills and among the outcomes targeted with the STEM education approach (Morrison, 2006; Aydın, Saka, \& Guzey, 2017; Partnership for 21st Century Skills, 2009), these skills were revealed in the scope of the research both in participant statements during semi-structured interviews and during observations completed during the research.

Risk and uncertainty factors in the concept of engineering make it necessary for students to learn from their mistakes and previous experience during the engineering design process (Moore et al., 2014). Engineering-based cognition skills are accepted as an important marker of the ability to learn from mistakes (National Research Council [NRC], 2009). During the study, though participants made mistakes several times, they solved these mistakes through decisions made as individuals and as a team. The results of interviews completed within the scope of the study observed participants became aware of mistakes made during the process and obtained skills like developing more effective designs and problem-solving to correct them. Additionally, they learned the transformation of basic scientific and mathematical concepts into applications with the RGM mechanism through trial and error. As a result, as stated in the NRC report, participants made progress on the topic of learning from mistakes, an important dimension of engineering-based cognition skills, during the process.

One of the basic philosophies of Rube Goldberg machines is that students involved in the design process use simple materials from daily life. The interview and observation data collected within the scope of this study show that students obtained all material used in the design process by recycling objects that were not used in their homes. In this way, arguments emphasized in the relevant literature about the learning activities encouraging individualized learning and strengthening the bonds between school and home were revealed (Song, 2016). Specific to Rube Goldberg machines, they are considered to provide the opportunity to create individually-meaningful design fields without requiring the use of developed technologies 
within the structure of the machines (Deveci, 2019). In this context, participants in the study used their own material for their designed RGM projects contributing to more individual and meaningful design and learning experiences.

Specific to STEM education, engineering applications target practical development about solving personal and social problems by students (Bybee, 2010; Guzey, Tank, Wang, Roehrig, \& Moore, 2014; Marulcu \& Sungur, 2013). Within the scope of this aim, interviews and observation data obtained from participants in this study revealed the positive development of problem-solving skills. While participants listed problem-solving at the top of the list of skills gained, observations revealed the participants used different strategies for problem-solving. Considering the complicated structure of RGM design, participants encountered problems with different types and levels and had the opportunity to produce solutions to these problems.

In this study, a design process independent of outcomes was completed through extracurricular activities. Though this process did not involve concerns about curriculum outcomes, within the process, the students displayed gains included in the primary school science and mathematics lesson curriculums and obtained upper-class outcomes too. Based on this, design activities not directly related to curriculum gains assessed in the free structure of extracurricular environments may be associated with knowledge and skills required by students. In addition, it allowed the possibility to gain awareness about upper-class outcomes. 


\section{References}

Acharya, S., \& Sirinterlikci, A. (2010). Introducing engineering design through an intelligent rube Goldberg implementation. Journal of Technology Studies, 36(2), 63-72.

Ambrose, D., \& Sternberg, R. J. (Eds.). (2016). Creative intelligence in the 21st century: Grappling with enormous problems and huge opportunities (Vol. 11). Springer.

Ambrose, D., \& Sternberg, R. J. (Eds.). (2016). Giftedness and talent in the 21st century: Adapting to the turbulence of globalization (Vol. 10). Springer.

Aydın, G., Saka, M., \& Guzey, S. (2017). 4-8. Sınıf Öğrencilerinin fen, teknoloji, mühendislik, matematik (STEM= FETEMM) tutumlarının incelenmesi. Mersin University Journal of the Faculty of Education, 13(2), 787-802.

Azgın, A. O., \& Şenler, B. (2019). İlkokulda STEM: Öğrencilerin kariyer ilgileri ve tutumları. Journal of Computer and Education Research, 7(13), 213-232.

Bahar, M., Yener, D., Y1lmaz M. \& Emen, H., Gürer, F. (2018). 2018 Fen bilimleri öğretim programı kazanımlarındaki değişimler ve fen teknoloji matematik mühendislik (STEM) entegrasyonu. Abant İzet Baysal Üniversitesi Eğitim Fakültesi Dergisi, 18(2), 702735.

Bevan, B., Gutwill, J. P., Petrich, M., \& Wilkinson, K. (2014). Learning through STEM-rich tinkering: Findings from a jointly negotiated research project taken up in practice. Science Education, 99(1), 98-120.

Brophy, S., Klein, S., Portsmore, M., \& Rogers, C. (2008). Advancing engineering education in P-12 classrooms. Journal of Engineering Education, 97(3), 369-387.

Bybee, R. W. (2010a). The teaching of science: 21 st century perspectives. Arlington, Virginia: NSTA Press.

Bybee, R. W. (2010b). Advancing STEM education: A 2020 vision. Technology and Engineering Teacher, 70(1), 30-35.

Bybee, R. W. (2010c). What is STEM Education. Science, 329, 996. doi:10.1126/science.1194998

Choi, E., Lindquist, R., \& Song, Y. (2014). Effects of problem-based learning vs. traditional 
lecture on Korean nursing students' critical thinking, problem-solving, and selfdirected learning. Nurse Education Today, 34(1), 52-56. doi:10.1016/j.nedt.2013.02.012

Davis, K. E. B., \& Hardin, S. E. (2013). Making STEM fun: How to organize a STEM. Teaching Exceptional Children, 45(4), 60-67.

Deveci, I. (2019). Reflections of Rube Goldberg machines on the prospective science teachers' STEM awareness. Contemporary Issues in Technology and Teacher Education, 19(2). Retrieved 25 July, 2018, from https://www.citejournal.org/volume-19/issue-219/science/reflections-of-rube-goldberg-machines-on-the-prospective-scienceteachers-stem-awareness

Hesser, T. L., \& Schwartz, P. M. (2013). iPads in the science laboratory: experience in designing and implementing a paperless chemistry laboratory course. Journal of STEM Education, 14(2), 5-9.

İnce, K., Mısır, M. E., Küpeli, M. A., \& Fırat, A. (2018). 5. sınıf fen bilimleri dersi yer kabuğunun gizemi ünitesinin öğretiminde STEM temelli yaklaşımın öğrencilerin problem çözme becerisi ve akademik başarısına etkisinin incelenmesi. Journal of STEAM Education, 1(1), 64-78.

Kim, Y., \& Park, N. (2012). Development and application of STEAM teaching model based on the Rube Goldberg's invention. In Computer science and its applications (pp. 693698). Springer, Dordrecht.

Mahinroosta, R., \& Lindsay, E. D. (2016). Rube Goldberg Machines as a transition to university tool. In 27th Annual Conference of the Australasian Association for Engineering Education: AAEE 2016 (p. 484). Southern Cross University.

Marulcu, İ., \& Sungur, K. (2012). Fen bilgisi öğretmen adaylarının mühendis ve mühendislik algılarının ve yöntem olarak mühendislik-dizayna bakış açılarının incelenmesi. Afyon Kocatepe Üniversitesi Fen ve Mühendislik Bilimleri Dergisi, 12(1), 13-23.

Milli Eğitim Bakanlığı Yenilik ve Eğitim Teknolojileri Genel Müdürlüğü (MEB YEĞİTEK GM) (2016). STEM Eğitimi Raporu. Retrieved July 29, 2019, from http://yegitek.meb.gov.tr/www/meb-yegitek-genel-mudurlugu-stem-fen-teknolojimuhendislik-matematik-egitim-raporu-hazirladi/icerik/719. 
Moore, T. J., Glancy, A. W., Tank, K. M., Kersten, J. A., Smith, K. A., \& Stohlmann, M. S. (2014). A framework for quality K-12 engineering education: Research and development. Journal of pre-college engineering education research (J-PEER), 4(1), 2.

Morrison, J. (2006). Attributes of STEM education: The student, the school, the classroom. Baltimore, MD: Teaching Institute for Excellence in STEM.

National Research Council. (2009). Engineering in K-12 education: Understanding the status and improving the prospects. Washington, DC: The National Academies.

National Research Council. (2012). A Framework for K-12 science education: Practices, crosscutting concepts, and core ideas. Washington DC: The National Academic Press.

Öner, A. T., \& Capraro, R. M. (2016). Is STEM academy designation synonymous with higher student achievement?. Education \& Science/Egitim ve Bilim, 41(185), 1-17.

Özyurt, M., Kayiran, B. K., \& Başaran, M. (2018). İlkokul öğrencilerinin STEM'e ilişkin tutumlarinin çeşitli değişkenler açisindan incelenmesi. Turkish Studies, 13(4), 65-82.

Partnership for 21st Century Skills. (2009). Framework for 21st century learning. Retrieved 25 July, 2019, from http://www.p21.org/storage/documents/P21_Framework.pdf.

Pekbay, C. (2017). Fen teknoloji mühendislik ve matematik etkinliklerinin ortaokul ögrrencileri üzerindeki etkileri. (Yayımlanmamış doktora tezi). Hacettepe Üniversitesi, Ankara.

Roberts, A. (2012). A justification for STEM education. Technology and engineering teacher, 71(8), 1-4.

Song, Y. (2016). "We found the 'black spots' on campus on our own": Development of inquiry skills in primary science learning with BYOD (Bring Your Own Device). Interactive Learning Environments, 24(2), 291-305.

Sahin, A. (2013). STEM clubs and science fair competitions: Effects on post-secondary matriculation. Journal of STEM Education, 14(1), 5-11.

Şimşek, H., \& Yıldırım, A. (2011). Sosyal bilimlerde nitel araştırma yöntemleri. Ankara: Seçkin Yayıncılık.

Topalsan, A. K. (2018). Sınıf öğretmenliği öğretmen adaylarının geliştirdikleri mühendislik tasarım temelli fen öğretim etkinliklerinin değerlendirilmesi. Yüzüncü Yıl Üniversitesi Ĕ̈itim Fakültesi Dergisi, 15(1), 186-219. 


\section{Appendix 1. Themes and Categories}

\begin{tabular}{|c|c|}
\hline Theme & Categories \\
\hline Design Process & $\begin{array}{l}\text { Abiding by sketch drawings } \\
\text { Bringing their own material } \\
\text { In-group decision making } \\
\text { Learning from mistakes }\end{array}$ \\
\hline Use of Disciplinary Knowledge & $\begin{array}{l}\text { Weight and force concepts } \\
\text { Thrust force } \\
\text { Force-energy relationship } \\
\text { Control of energy transfer } \\
\text { Problem statements and solving } \\
\text { Use of nonstandard measurement tools }\end{array}$ \\
\hline Use of Skills & $\begin{array}{l}\text { Cognition skills, } \\
\text { Lack of association with skills } \\
\text { Manual skills } \\
\text { Problem-solving skills } \\
\text { Communication and cooperation skills } \\
\text { Creativity }\end{array}$ \\
\hline Difficulties during Implementation & $\begin{array}{l}\text { Problems experienced during step transfers } \\
\text { Inability to clarify RGM steps } \\
\text { Difficulties due to attention errors }\end{array}$ \\
\hline Problem Solving & $\begin{array}{l}\text { Problem-solving with trial and error } \\
\text { Problem-solving by discussion } \\
\text { Mentor support } \\
\text { Determining most appropriate solution } \\
\text { Focused problem-solving }\end{array}$ \\
\hline $\begin{array}{l}\text { Team work, Cooperation and } \\
\text { Communication }\end{array}$ & $\begin{array}{l}\text { Communication problems } \\
\text { Cooperative problem-solving } \\
\text { Solution by consensus in discussions } \\
\text { Sharing responsibilities and duties } \\
\text { Listening and applying ideas }\end{array}$ \\
\hline $\begin{array}{l}\text { Comparison of Project and In-class } \\
\text { Implementation }\end{array}$ & $\begin{array}{l}\text { Similarity to in-class experiments (direct experience of the student) } \\
\text { Richer experiences compared to in-class implementations } \\
\text { Possibility for more cooperative work } \\
\text { Completion of each week regularly } \\
\text { Three dimensional, experienced-focused work, different from books }\end{array}$ \\
\hline Learning & $\begin{array}{l}\text { Project design and development } \\
\text { Slope velocity relationship } \\
\text { Slope plane system }\end{array}$ \\
\hline Role of the Educator & $\begin{array}{l}\text { Supporting with clues } \\
\text { Correcting mistakes } \\
\text { Undertaking the role of teacher } \\
\text { Providing awareness of problems } \\
\text { Making them aware of errors }\end{array}$ \\
\hline
\end{tabular}

